\title{
Aggressive keloid-mimicking tumor in Melanosuchus niger in captivity
}

\author{
Queloide agressivo imitando tumor em Melanosuchus niger em cativeiro
}

Washington Luiz Assunção Pereira ${ }^{\mathrm{I}}$ Antônio Messias Costa ${ }^{\mathrm{II}}$ Aline Amaral Imbelonii ${ }^{\mathrm{II}}$
Thatiana de Andrade Figueiredo ${ }^{\mathrm{II}}$ Klena Sarges Marruaz da Silva ${ }^{\mathrm{IV}}$

\section{- NOTE -}

\section{ABSTRACT}

The objective of this note is to describe a case of exuberant scarring formation, with keloid characteristics and pseudo-tumoral configuration in a male Black caiman (Melanosuchus niger), with an estimated age of 60 years, belonging to the Zoobotanical Park at the Emílio Goeldi Museum, located in Belém, Pará, Brazil. The alteration appeared on the right posterior limb involving two distal phalanges of the lateral digit and measured $12.4 \mathrm{~cm}$ at the greatest width. The keloid tissue was surgically removed and samples were processed and analyzed histopathologically, revealing growth made up of fibrous connective tissue with the habitual morphology, which was structurally mature in the more central areas.

Key words: skin lesion, Black caiman, Melanosuchus niger, keloid.

RESUMO

O objetivo do presente relato é descrever um caso de formação cicatricial exuberante, característica de queloide e configuração pseudo-tumoral em um jacaré-açu (Melanosuchus niger), macho, com idade estimada de 60 anos, pertencente ao Parque Zoobotânico do Museu Emílio Goeldi, situado em Belém, Pará, Brasil. A alteração manifestou-se no membro posterior direito, envolvendo as duas falanges distais do dedo lateral $e$ mediu 12,4cm na maior largura. A neoformação foi removida cirurgicamente e amostras foram processadas e analisadas por histopatologia, que revelou crescimento constituído por tecido conjuntivo fibroso de morfologia habitual, estando estruturalmente maduro nas áreas mais centrais.

Palavras-chave: lesão cutânea, jacaré-açu, Melanosuchus niger, Queloide.
There are three genera of Amazonian crocodilans, Caiman, Melanosuchus and Paleosuchus. The black caiman (Melanosuchus niger) belongs to the order Crocodilia and family Alligatoridae. This species and the spectacled caiman (Caiman crocodilus) deserve special attention because they were heavily hunted in the past and today are undergoing a population recovery. The two species are the most abundant crocodilians in the Brazilian Amazon (VASCONCELOS, 2005).

As is the case of various other crocodilian species, they are quite resistant in captivity, although they are vulnerable to plantar abrasions when kept on substrates that have hardened over time, which may also be related to their greater weight and more fragile skin (COSTA, 2010 - personal communication). They also tend towards having diseases common to the group, such as: omphalitis, wounds from fighting, viral dermatitis, uric gout, nutritional hypoproteinemia, nutritional hyperthyroidism, and general adaptation syndrome (stress) (SARKIS-GONÇALVES et al., 2001).

With regard to diseases in crocodilians, BUENVIAJE et al. (1998) carried out a study on skin diseases among crocodiles ranched in Australia and recorded the following frequency of primary pathogens: Dermatophilus sp. 28,1\%, fungi 14,8\%, poxvirus 3,4\% and Mycobacterium sp. 2,5\% and there was one case of infection by the Paratrichosoma

\footnotetext{
Instituto da Saúde e Produção Animal (ISPA) of the Universidade Federal Rural da Amazônia (UFRA), CP 917, 66077-530, Belém, PA, Brasil. E-mail: wkarton@terra.com.br. Autor para correspondência.

IIParque Zoobotânico do Museu Paraense Emílio Goeldi, Belém, PA, Brasil.

IIIParque Mangal das Garças, Belém, PA, Brasil.

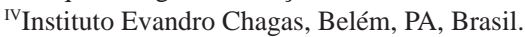


nematode, while multiple agents were present in $32.5 \%$ of the lesions.

Non-infectious pathology in reptiles presents rare reports of neoplasias in crocodilians, as well as those of a proliferative nature (GARNER, 2004), with few cases of either being described in the literature. This note thus has the objective of describing a case of exuberant keloidal formation with a tumoral aspect in Melanosuchus niger. This is apparently the first report of this pathological process in a crocodilian kept in captivity.

The object of this study is a senile male specimen of Melanosuchus niger, (approximately 60 years of age), with a length of $4.5 \mathrm{~m}$, belonging to the Zoobotanical Park at the Emílio Goeldi Museum, in Belém, Pará, Brazil. The alteration manifested itself slowly, and came to involve the entire lateral digit of the back right leg, measuring $12.4 \mathrm{~cm}$ at its greatest width (Figure 1a) with a weight of 500g. Morphologically, the pseudotumor growth presented a spheroidal form and purplish-red tissue, similar to what had been described by AROSEMENA \& AROSEMENA (2007) for keloids. The process was covered by a grayishwhite film containing small fissures.

To carry out the surgical procedures (resection of the formation) the animal was induced to enter a containment cage where it was easily immobilized. With the animal's mouth immobilized and its eyes covered the neoformation was peripherically infiltrated with $2 \%$ lindocaine chloride at the base, with support from a rubber tourniquet placed slightly above the region of the surgery. It was made the divulsion of the neoformation and of the third phalange with a surgical scissor which was subsequently removed. The surgical suture was made with 1.0 nylon thread, being careful to don't drop the suture, so it was made the heating of the ends. Tissue fragments were fixed in a $10 \%$ neutral formalin solution and processed for histopathological analysis.

The post-operatory phase involved antibiotic therapy (enrofloxacin $2 \mathrm{mg} \mathrm{kg}^{-1}, \mathrm{IM}$ ), and complex B (15ml, IM), both at a two-day interval administered via blow dart; for topical treatment of the surgical wound an iodoform solution was used.

Under microscopic examination the tissue presented a single pattern of conjunctive constitution, at the surface revealing a thick layer of eosinophilic covering, with characteristics of crust wound undergoing scarring. The mass of conjunctive tissue peculiar to the keloid showed itself to be more active, with a greater number of cells and vessels (granulation tissue) at the more superficial levels of the proliferation (Figure 1b). In the more internal areas the conjunctive tissue presented a fibrovascular constitution, usually loose with a light infiltration of eosinophils (Figure 2).

AROSEMENA \& AROSEMENA (2007) describe the keloid scar as a lesion having a tumoral aspect. The authors point out that despite decades of research in the area of wound scarring, the physiopathology of hypertrophic scars and keloids are not yet fully understood.

LOUW (2007) states that keloids are like benign tumors that are formed due to the dermal proliferation of fibroblasts and excessive production of collagen and that their causal factor may be trauma. Furthermore, during an abnormal wound healing process a hypertrophic and/or keloid-type scar may

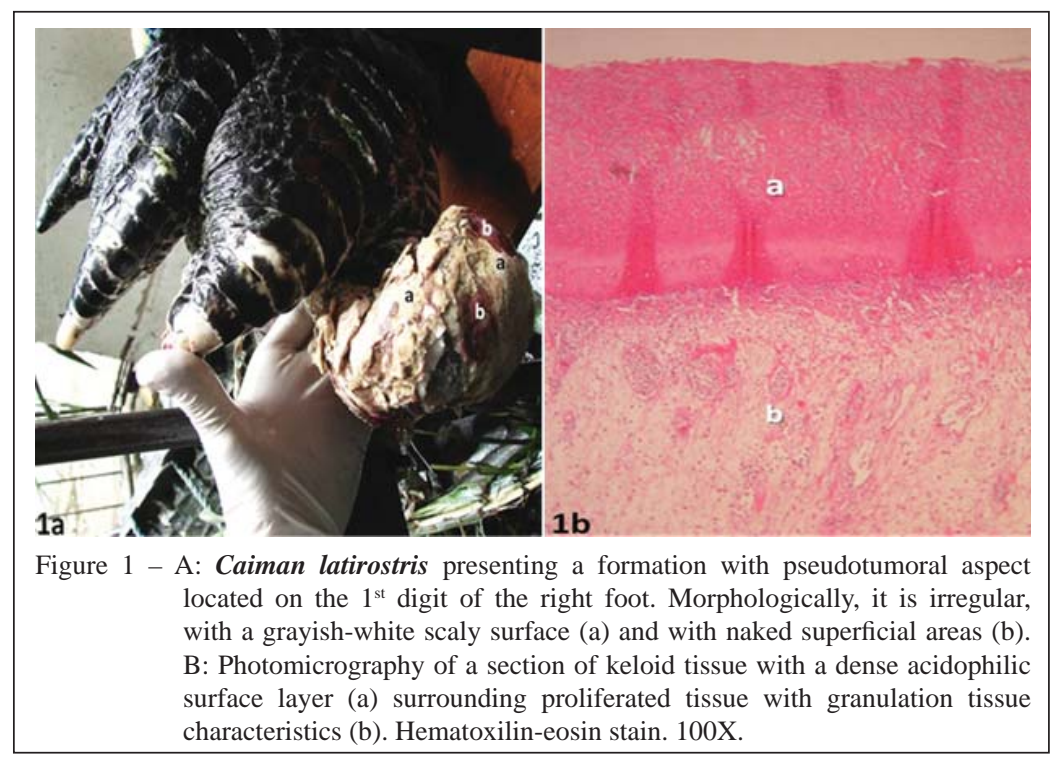

Ciência Rural, v.43, n.7, jul, 2013. 


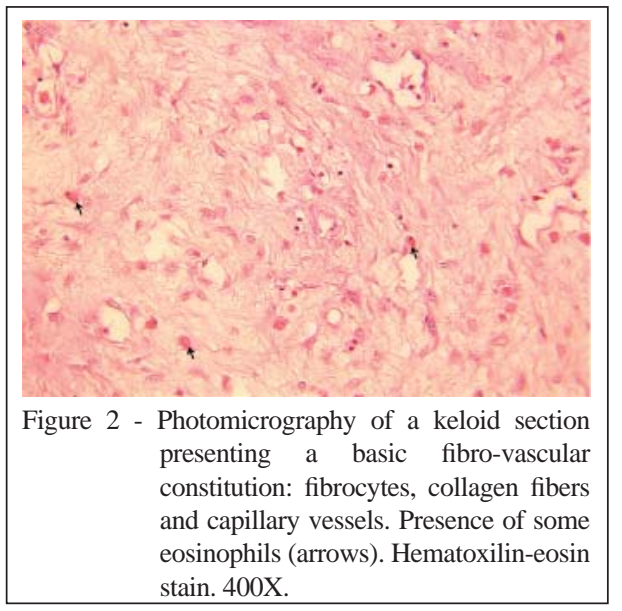

occur, which will depend upon the length of exposure of the fibroblasts to micro-environment influences that will alter the cellular and molecular processes, leaving to an increase in collagen production. For their part AROSEMENA \& AROSEMENA (2007), describe the keloid scar as having a tumoral aspect. However, the authors unanimously accept that the scarring process in wounds and the physiopathology of the hypertrophic scar and keloid are not yet fully understood.

In an abnormal wound healing process the formation of a hypertrophic-type and/or keloid-type scar may occur. Whether the scar is hypertrophic or keloidal will depend on the length of exposure of the fibroblasts to the influences of the micro-environment that alters cellular and molecular processes, which conduct to an increase in production of collagen (LOUW, 2007).

CAMPANER et al. (2007) confirms the poor understanding regarding molecular mechanisms that lead to the formation of keloids and hypertrophic scars. They mentioned the lack of an appropriate animal model for the process, considering that those processes occur only in humans. However, for various authors the most accepted theory related to the formation of such scars is based on the expression of regulation of TGF-b1 (Transforming Growth Factor beta 1).

In contrast to hypertrophic scarring a keloid is composed of disorganized type I and II collagen fibers, with little cellularity, with neither excess of fibroblasts nor formation of nodules (AROSEMENA \& AROSEMENA, 2007). Those histological characteristics described for the keloid were observed in this study.

MUKHOPADHYAY et al. (2007) state that the differential diagnosis for a keloid is made with a soft fibroma, and describe that neoplasia as being made up of few fibroblasts and clusters of collagen fibers, with adipose cells present in many cases. It should be noted that there are differences between scar tissue and fibroma-type tumoral tissue, as described by MOVASSAGHI \& MOHAMMADI (2009), where the fibroma presents mature fusiform fibrocytes with oval normochromatic nuclei and abundant collagen organized in bundles.

However, MIKAELIAN \& GROSS (2002) use the term fibroma or keloidal fibrossarcoma for cutaneous nodules or plaques in dogs, which, histologically, are focal dermal and/or subcutaneous depositions of thickened and hyalinized collagen fibers mixing with fibroblasts.

From the literature consulted one may conclude that the keloid-type scarring process is not very clear in terms of its etiopathogeny, even less so in crocodilians in which the occurrence is rare, and that scarring reactions may manifest themselves as a well-developed process that acquires a pseudotumoral aspect.

\section{ACKNOWLEDGEMENTS}

The authors are grateful to $\mathrm{Mr}$ Osvaldo Leal Santos (National Primate Center -IEC/SVS/MS) for help us with the preparation of the tissues.

\section{BIOETHICS \\ AND BIOSSECURITY COMMITTEE}

Vimos através desta nos responsabilizar pelos aspectos éticos adotados nos procedimentos realizados que resultaram na publicação do artigo científico intitulado "Agressive keloid-mimicking tumor in Melanosuchus niger (SPIX, 1825) in captivity” (Quelóide agressivo imitando tumor em Melanosuchus niger (SPIX, 1825) em cativeiro).

\section{PERSONAL COMMUNICATION}

Parque Zoobotânico Museu Paraense Emílio Goeldi messias@museu-goeldi.br - Belém -PA - 2010.

\section{REFERENCES}

AROSEMENA, A.S.; AROSEMENA, R.S. Actualización sobre el queloide y la cicatriz hipertrófica. Act Terap Dermatol, v.30, p.238-244, 2007.

BUENVIAJE, G.N. et al. Patologia das doenças de pele em crocodilos. Aust Vet J, v.76, p.357-363, 1998.

CAMPANER, A.B. et al. Modelo animal de quelóide utilizando fibroblastos modificados geneticamente. Rev Soc Bras Cir Plást, v.22, n.3, p.137-142, 2007. 
GARNER, M.M. Trends in reptilian neoplasia: a diagnostician's perspective. Lecture. In: ANNUAL MEETING OF THE ACVP, 55.; ANNUAL MEETING OF THE ASVCP, 39, 2004, Ithaca. Proceedings... Ithaca, New York: ACVP, 2004.

LOUW, L. The keloid phenomenon: progress toward a solution review. Clin Anat, v.20, p.3-14, 2007.

MIKAELIAN, I.; GROSS, T.L. Keloidal fibromas and fibrosarcomas in the dog. Vet Pathol, v.39, p.149-153, 2002.

MOVASSAGHI, A.R.; MOHAMMADI, G.H. An unusual cutaneous fibroma in a heifer. Comp Clin Pat, v.18, n.2, p.207208, 2009.
MUKHOPADHYAY, A. et al. The role of the activin system in keloid pathogenesis. Am J Physiol Cell Physiol, v.292, p.1331-1338, 2007.

SARKIS-GONÇALVES, F. et al. Manejo de jacarés-de-papoamarelo (Caiman latirostris) em cativeiro. In: MATTOS, W.R.S. (Ed.). A produção animal na visão dos brasileiros. Piracicaba: Sociedade Brasileira de Zootecnia, 2001. p.565-579.

VASCONCELOS, W.R. Diversidade genética e estrutura populacional dos crocodilianos jacaré-açú (Melanosuchus niger) e jacaré-tinga (Caiman crocodilus) da Amazônia. Biota Neotrop, v.5, n.2, p.0-0, 2005. 